\title{
Geothermometric evaluation of geothermal resources in southeastern Idaho
}

\author{
G. Neupane ${ }^{1,2}$, E. D. Mattson ${ }^{1}$, T. L. McLing ${ }^{1,2}$, C. D. Palmer ${ }^{3}$, R. W. Smith ${ }^{3}$, T. R. Wood ${ }^{4}$, and \\ R. K. Podgorney ${ }^{1}$ \\ ${ }^{1}$ Idaho National Laboratory, Idaho Falls, Idaho, USA \\ ${ }^{2}$ Center for Advanced Energy Studies, Idaho Falls, Idaho, USA \\ ${ }^{3}$ Office of Research \& Economic Development, University of Idaho, Moscow, Idaho, USA \\ ${ }^{4}$ Department of Geological Sciences, University of Idaho - Idaho Falls, Idaho Falls, Idaho, USA \\ Correspondence to: G. Neupane (ghanashyam.neupane@inl.gov)
}

Received: 11 June 2015 - Revised: 3 December 2015 - Accepted: 9 December 2015 - Published: 15 January 2016

\begin{abstract}
Southeastern Idaho exhibits numerous warm springs, warm water from shallow wells, and hot water from oil and gas test wells that indicate a potential for geothermal development in the area. We have estimated reservoir temperatures from chemical composition of thermal waters in southeastern Idaho using an inverse geochemical modeling technique (Reservoir Temperature Estimator, RTEst) that calculates the temperature at which multiple minerals are simultaneously at equilibrium while explicitly accounting for the possible loss of volatile constituents (e.g., $\mathrm{CO}_{2}$ ), boiling and/or water mixing. The temperature estimates in the region varied from moderately warm $\left(59^{\circ} \mathrm{C}\right)$ to over $175^{\circ} \mathrm{C}$. Specifically, hot springs near Preston, Idaho, resulted in the highest reservoir temperature estimates in the region.
\end{abstract}

\section{Introduction}

The state of Idaho in the US has high potential of geothermal energy. The US Geological Survey has estimated that there is up to $4900 \mathrm{MWe}$ of undiscovered geothermal resources and $92000 \mathrm{MWe}$ of enhanced geothermal potential within the state (Williams et al., 2008). Southern Idaho has been regarded to have high geothermal potential for conventional as well as for enhanced geothermal system (EGS) development (Tester et al., 2006). Geologic evidence such as the passage of the Yellowstone hotspot, Pleistocene basaltic flows, young volcanic features, and warm to hot springs (Mitchell, 1976a, b; Ralston et al., 1981; Souder, 1985) in southern Idaho indicate that the area may have economically viable geothermal resources. More direct evidence of a high-temperature regime at depth in the area is provided by a limited number of deep wells with high bottom-hole temperatures (BHTs) such as the King 2-1 well $\left(202^{\circ} \mathrm{C}\right.$, Table 1). Despite this geologic evidence and high BHTs, estimates of reservoir temperature based on traditional geothermometers applied to the chemistry of waters from springs in the region generally suggest a moderate temperature (Mitchell, 1976a, b).
As a part of an effort to assess the geothermal potential of southern Idaho, we assembled chemical composition of waters measured from numerous springs and wells in the region and used them to estimate reservoir temperatures using an inverse geochemical modeling tool (Reservoir Temperature Estimator, RTEst; Mattson et al., 2015). In this paper, we present results of RTEst applied to southern Idaho thermal water measured at a number of wells and springs.

\section{Geology and geothermal setting of the area}

\subsection{Geology}

The study area is located in both the Basin and Range and Rocky Mountains provinces. Specifically, the western part of the area has geographic characteristics of the Basin and Range such as wide and sediment-filled basins separating fault-bound ranges, whereas the eastern part consists of several thrust-bound narrow sub-parallel ridges with thinly filed basins (Mabey and Oriel, 1970). Geologically, the foldthrust belt (Fig. 1a) in the area is a part of Sevier fold-thrust 


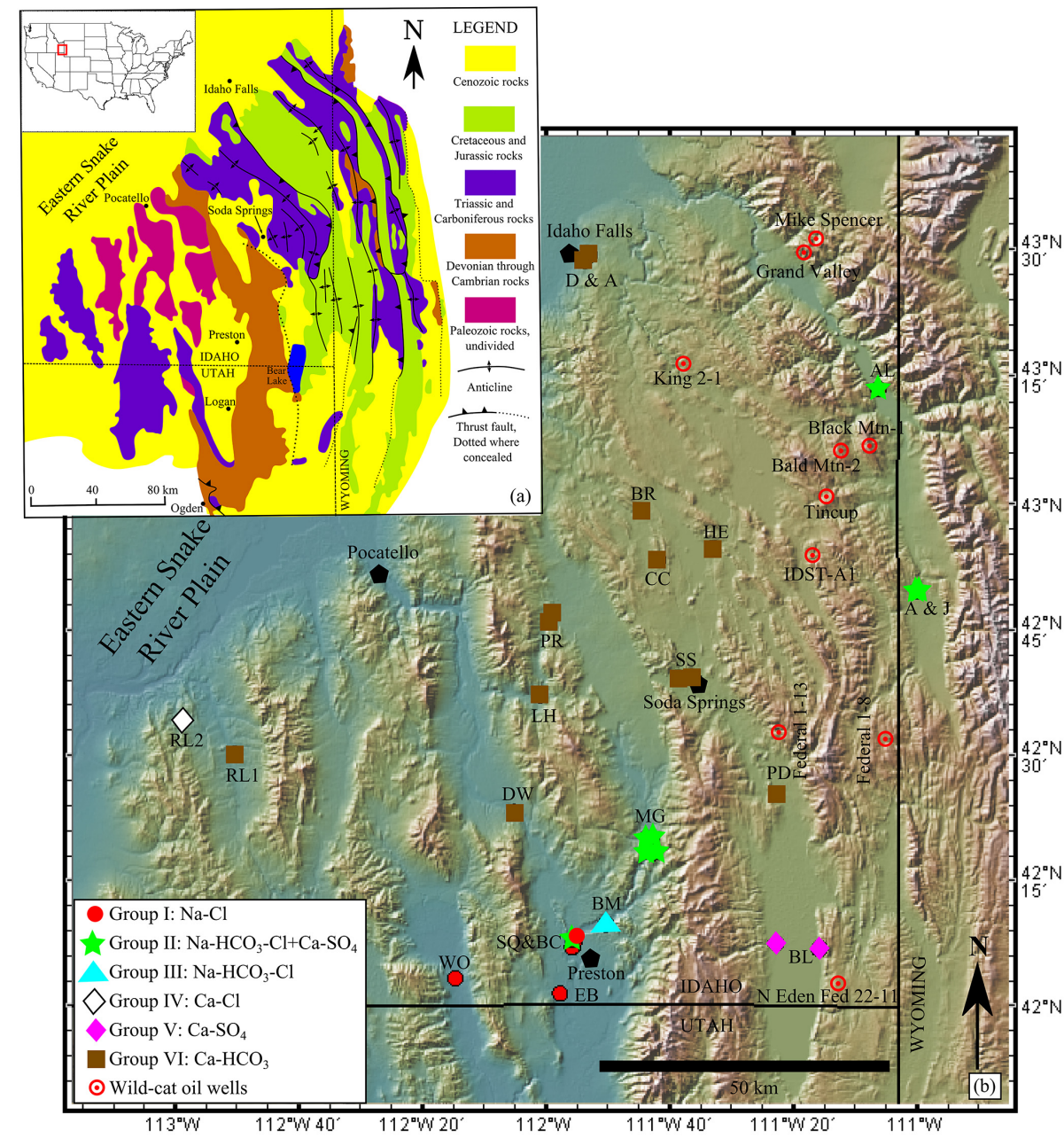

Figure 1. (a) Simplified geologic map of Idaho-Wyoming fold-thrust belt (Armstrong and Oriel, 1965). (b) Selected springs/wells and general water composition types in southeastern Idaho. The springs/wells codes correspond to the map code given in Table 2 . The shaded relief map prepared from NASA $10 \mathrm{~m}$ digital elevation model data in GeoMapApp.

zone, locally known as the Idaho-Wyoming fold-thrust belt (Armstrong and Oriel, 1965).

Geology of the area includes thick sequences Paleozoic and Mesozoic carbonate-rich sedimentary rocks deposited in a passive margin setting (Armstrong and Oriel, 1965). During the Jurassic-Cretaceous periods these sedimentary sequences were deformed by compressive stresses associated with the Sevier orogeny resulting in numerous west-dipping low-angled thrust faults (Armstrong and Oriel, 1965). Starting in the Eocene and continuing to the Recent, extensional activities resulted in Basin and Range type topography with normal faults bounding ranges and wide valleys (Armstrong and Oriel, 1965; Dixon, 1982). Quaternary volcanic activity in some areas in the region (McCurry et al., 2011) resulted in volcanic resources (McCurry et al., 2008; Pickett, 2004).

\subsection{Geothermal setting}

The presence of several hot springs and warm springs indicates potential geothermal resources in southeastern Idaho. The western part of study area represents the amagmatic Basin and Range type geothermal system where convective upwelling dominates the thermal discharge along the extensional faults. The discharges of thermal water from springs and seeps in eastern and northern parts of the study area are also controlled by deep normal faults (Dansart et al., 1994). However, some recent works (e.g., McCurry et al., 2011; Welhan et al., 2014) also suggest a deep magmatic geothermal resource in this area. The conceptual model of magmatic-sourced geothermal setting in the fold-thrust belt in southeastern Idaho considers a magmatic geothermal resource at a depth of $12-14 \mathrm{~km}$ in an area beneath $58 \mathrm{ka}$ rhyolite domes at China Hat located within the Blackfoot Volcanic Field (BVF) (Welhan et al., 2014). According to this hypothesis, the deep-sourced magmatic hydrothermal fluid 
Table 1. Depth and corrected bottom-hole temperatures (BHTs) of several wildcat oil exploration wells in southeastern Idaho (Ralston et al., 1981; Souder, 1985; Blackwell et al., 1992; Welhan and Gwynn, 2014).

\begin{tabular}{lrr}
\hline Wells & Depth $(\mathrm{m})$ & $\mathrm{BHT}\left({ }^{\circ} \mathrm{C}\right)$ \\
\hline King 2-1 & 3927 & 202 \\
Grand Valley & 4931 & 140 \\
Mike Spencer Canyon & 4259 & 112 \\
Bald Mountain-2 & 3830 & 140 \\
Black Mountain-1 & 4158 & 120 \\
Federal 1-8 & 5105 & 167 \\
Big Canyon Federal 1-13 & 3551 & 172 \\
IDST-A1 & 4952 & 183 \\
Tincup & 5059 & 180 \\
N Eden Federal 21-11 & 2618 & 84 \\
\hline
\end{tabular}

from this zone migrates eastwards along the thrust faults and permeable Paleozoic and Mesozoic layers into a shallower (3-5 km) reservoir. The high-temperature and high-salinity (sodium chloride) thermal fluids encountered at depth in some deep wildcat petroleum wells (such as, the King 2-1 well in Table 1) are possibly associated with these migrated magmatic fluids (Welhan et al., 2014).

\section{Southeastern Idaho water chemistry data}

Chemical compositions of numerous water samples from southeastern Idaho were assembled to assess the potential geothermal reservoir temperatures in the region. Over the last several decades, water samples from springs and wells in southeastern Idaho have been analyzed by several US government agencies and researchers for water quality and management, environmental remediation, and geothermal energy exploration (e.g., Young and Mitchell, 1973; Mitchell, 1976a, b; Ralston et al., 1981; Souder, 1985; Avery, 1987; McLing et al., 2002). A database is compiled of publicly available data for southeastern Idaho springs/wells. From a larger database, 50 water compositions (Table 2, Fig. 1b) were selected for the assessment of deep geothermal temperatures in southeastern Idaho.

\section{Geothermometry}

\subsection{Approach}

Geothermometry is a low-cost but useful geothermal exploration tool that uses the chemical compositions of water from springs and wells to estimate reservoir temperature. The application of geothermometry requires several assumptions: (1) the reservoir minerals and fluid attain chemical equilibrium, and (2) the water that moves from the reservoir to the sampling location retains its chemical signatures (Fournier et al., 1974). The first assumption is generally valid (provided there is a sufficiently long residence time); however, the second assumption is more likely to be violated. As reservoir fluids move toward the surface, the pressure on the fluid decreases resulting in boiling and subsequent loss of volatiles (e.g., $\mathrm{CO}_{2}$ ). The fluid temperature will decrease as a result of the associated heat of vaporization as well as thermal conduction. Boiling will increase the concentrations of non-volatile components in the liquid phase. The loss of acid volatiles such as $\mathrm{CO}_{2}$ and $\mathrm{H}_{2} \mathrm{~S}$ will alter the $\mathrm{pH}$ while the loss of redox active species such as $\mathrm{H}_{2} \mathrm{~S}$ can shift the ratios of redox pairs (e.g., $\mathrm{HS}^{-} / \mathrm{SO}_{4}^{2-}$ ). These changes in temperature and solute concentrations may result in re-equilibration of the liquid phase with minerals in the zone above the main reservoir. In addition, this altered thermal water may mix with nonthermal waters which will further alter solute concentrations. These processes mask the initial geochemical signature of the reservoir fluid resulting in temperature estimates from traditional geothermometers being diverse and often being inaccurate or inconclusive.

Geothermal temperature predictions using multicomponent equilibrium geothermometry (MEG) provide apparent improvement in reliability and predictability of temperature over traditional geothermometers. The basic concept of this method was developed in the 1980s (e.g., Michard and Roekens, 1983; Reed and Spycher, 1984), and some investigators (e.g., D'Amore et al., 1987; Hull et al., 1987; Tole et al., 1993) have used this technique for predicting geothermal temperature in various geothermal settings. Other researchers have used the basic principles of this method for reconstructing the composition of geothermal fluids and formation brines (Pang and Reed, 1998; Palandri and Reed, 2001). More recent efforts (e.g., Bethke, 2008; Spycher et al., 2011, 2014; Smith et al., 2012; Cooper et al., 2013; Neupane et al., 2013, 2014, 2015a, b; Peiffer et al., 2014; Palmer et al., 2014; Mattson et al., 2015) have been focused on improving temperature predictability of the MEG.

An additional advantage of MEG over traditional geothermometers is that it considers a suite of chemical data obtained from water analyses for temperature estimation. Although MEG has advantages over the traditional geothermometers, it is also subject to the same physical and chemical processes that can violate the basic assumptions of geothermometry. However, MEG also provides a quantitative approach to account for subsurface composition-altering physical and chemical processes through inverse geochemical modeling. Therefore, it is important to reconstruct the composition of geothermal water for estimation of reservoir temperature with a greater certainty.

A newly developed geothermometry tool known as Reservoir Temperature Estimator (RTEst) (Palmer et al., 2014; Mattson et al., 2015) is used to estimate geothermal reservoir temperatures in southeastern Idaho. The RTEst is an inverse geochemical tool that implements MEG with an optimization capability to account for processes such as boiling, mixing, and gas loss. A more detailed description about RTEst can 
Table 2. Water compositions of selected hot/warm springs and wells in southeastern Idaho used for temperature estimation. Elemental/species concentrations are given in $\mathrm{mg} \mathrm{L}^{-1}$. The $\mathrm{pH}$ was measured in the field.

\begin{tabular}{|c|c|c|c|c|c|c|c|c|c|c|c|c|c|c|}
\hline Springs/wells ${ }^{\mathrm{a}}$ & $\mathrm{T}\left({ }^{\circ} \mathrm{C}\right)$ & $\mathrm{pH}$ & $\mathrm{Na}$ & $\mathrm{K}$ & $\mathrm{Ca}$ & $\mathrm{Mg}$ & $\mathrm{SiO}_{2(\mathrm{aq})}$ & $\mathrm{HCO}_{3}$ & $\mathrm{SO}_{4}$ & $\mathrm{Cl}$ & $\mathrm{F}$ & $\begin{array}{l}\text { Map } \\
\text { code }^{b}\end{array}$ & $\begin{array}{l}\text { Water } \\
\text { type }\end{array}$ & $\begin{array}{c}\text { Data } \\
\text { source }^{\mathrm{d}}\end{array}$ \\
\hline Woodruff WS & 27 & 7.3 & 910 & 87 & 130 & 45 & 29 & 454 & 58 & 1600 & 0.6 & WO & I & 1 \\
\hline E. Bingham W & 63 & 6.2 & 4600 & 770 & 320 & 36 & 68 & 930 & 48 & 7800 & 3.9 & EB & & 1 \\
\hline Squaw HS-1 & 69 & 6.5 & 4184 & 708 & 135 & 23 & 126 & 816 & 27 & 6877 & 4.3 & SQ \& BC & & 2 \\
\hline Squaw HS-2 & 73 & 6.6 & 3844 & 533 & 241 & 26 & 126 & 866 & 23 & 6396 & 4.8 & & & 2 \\
\hline Squaw HS W-1 & 82 & 7.8 & 4300 & 880 & 250 & 23 & 130 & 733 & 54 & 7700 & 7 & & & 3 \\
\hline Squaw HS W-2 & 84 & 6.5 & 4368 & 782 & 279 & 24 & 124 & 791 & 35 & 7398 & 4.3 & & & 2 \\
\hline Squaw HS W-3 & 82 & 6.9 & 3996 & 694 & 261 & 21 & 139 & 725 & 35 & 7291 & 4.9 & & & 1 \\
\hline Battle Creek HS-1 & 43 & 6.7 & 3161 & 552 & 174 & 19 & 109 & 696 & 35 & 5241 & 6 & & & 2 \\
\hline Battle Creek HS-2 & 77 & 6.5 & 3071 & 535 & 166 & 15 & 107 & 697 & 29 & 5048 & 6 & & & 2 \\
\hline Battle Creek HS-3 & 81 & 6.5 & 3053 & 533 & 162 & 19 & 109 & 757 & 37 & 5034 & 6 & & & 2 \\
\hline Battle Creek HS-4 & 82 & 6.8 & 4184 & 686 & 215 & 24 & 97 & 610 & 33 & 6967 & 6.4 & & & 2 \\
\hline Wayland HS-1 & 84 & 7 & 3100 & 660 & 160 & 16 & 80 & 699 & 50 & 5400 & 12 & & & 3 \\
\hline Alpine WS & 37 & 6.5 & 1500 & 180 & 560 & 100 & 40 & 880 & 1000 & 2800 & 2.7 & $\mathrm{AL}$ & II & 1 \\
\hline Wayland HS-2 & 77 & 6.9 & 499 & 77 & 82 & 22 & 64 & 454 & 323 & 585 & 1 & $\mathrm{SQ} \& \mathrm{BC}$ & & 1 \\
\hline Treasurton WS-1 & 35 & 6.6 & 563 & 127 & 265 & 68 & 54 & 704 & 788 & 632 & 2.2 & MG & & 2 \\
\hline Treasurton WS-2 & 40 & 6.4 & 542 & 110 & 336 & 48 & 54 & 726 & 735 & 629 & 2 & & & 1 \\
\hline Cleavland WS & 55 & 6.2 & 444 & 90 & 259 & 41 & 62 & 565 & 517 & 574 & 1.7 & & & 1 \\
\hline Maple Grove HS-1 & 72 & 7.3 & 490 & 110 & 89 & 24 & 55 & 491 & 260 & 630 & 1.1 & & & 3 \\
\hline Maple Grove HS-2 & 60 & 6.8 & 501 & 82 & 93 & 29 & 85 & 495 & 261 & 601 & 1.1 & & & 2 \\
\hline Maple Grove HS-3 & 76 & 6.8 & 492 & 80 & 93 & 25 & 86 & 494 & 251 & 584 & 1 & & & 2 \\
\hline Maple Grove HS-4 & 71 & 7.8 & 494 & 76 & 69 & 31 & 52 & 424 & 255 & 595 & 0.9 & & & 4 \\
\hline Maple Grove HS-5 & 78 & 6.6 & 492 & 82 & 85 & 30 & 84 & 494 & 256 & 596 & 1.1 & & & 2 \\
\hline Maple Grove HS-6 & 75 & 6.3 & 550 & 71 & 132 & 24 & 66 & 466 & 282 & 586 & 0.3 & & & 1 \\
\hline Auburn HS & 57 & 6.4 & 1327 & 162 & 509 & 76 & 68 & 822 & 996 & 1737 & 0.6 & $A \& J$ & & 1 \\
\hline Johnson S & 54 & 6.4 & 1494 & 176 & 454 & 45 & 88 & 973 & 1129 & 1947 & & & & 1 \\
\hline Ben Meek W-1 & 40 & 7.4 & 348 & 20 & 23 & 5 & 90 & 526 & 5 & 321 & 11 & $\mathrm{BM}$ & III & 1 \\
\hline Ben Meek W-2 & 45 & 7.3 & 360 & 24 & 25 & 7 & 80 & 524 & 15 & 320 & 10 & & & 1 \\
\hline Ben Meek W-3 & 40 & 6.9 & 368 & 22 & 24 & 7 & 89 & 513 & 13 & 322 & 9.6 & & & 1 \\
\hline Rockland W-2 & 20 & 7.3 & 60 & 24 & 120 & 22 & 70 & 220 & 26 & 280 & 0.2 & RL2 & IV & 5 \\
\hline Bear Lake HS-1 & 40 & 7 & 155 & 48 & 230 & 41 & 43 & 263 & 769 & 72 & 4.2 & $\mathrm{BL}$ & V & 1 \\
\hline Bear Lake HS-2 & 39 & 7.2 & 151 & 44 & 227 & 41 & 46 & 255 & 791 & 75 & 4.2 & & & 1 \\
\hline Bear Lake HS-3 & 33 & 7.1 & 163 & 43 & 227 & 41 & 40 & 271 & 758 & 74 & 4 & & & 1 \\
\hline Bear Lake HS-4 & 48 & 6.6 & 180 & 61 & 210 & 55 & 35 & 256 & 800 & 79 & 7.1 & & & 1 \\
\hline Downata HS & 43 & 6.7 & 20 & 9 & 43 & 15 & 29 & 214 & 18 & 20 & 0.4 & DW & VI & 1 \\
\hline Black River WS & 26 & 6.2 & 147 & 217 & 674 & 245 & 33 & 2357 & 1132 & 110 & 3.7 & $\mathrm{BR}$ & & 6 \\
\hline Pescadero WS & 26 & 6.4 & 63 & 14 & 188 & 65 & 31 & 658 & 225 & 83 & 1.8 & PD & & 1 \\
\hline Henry WS & 20 & 6.4 & 25 & 8 & 284 & 44 & 40 & 870 & 145 & 32 & 1 & $\mathrm{HE}$ & & 1 \\
\hline Steamboat HS & 51 & 7 & 28 & 27 & 645 & 248 & 84 & 2380 & 472 & 8 & 0.3 & SS & & 7 \\
\hline Soda Springs G & 28 & 6.5 & 12 & 23 & 851 & 193 & 35 & 2613 & 801 & 6 & 1.6 & & & 1 \\
\hline Lava HS-1 & 45 & 6.6 & 170 & 39 & 120 & 32 & 32 & 542 & 110 & 190 & 0.7 & $\mathrm{LH}$ & & 3 \\
\hline Lava HS-2 & 43 & 6.7 & 176 & 37 & 103 & 29 & 35 & 528 & 91 & 179 & 0.7 & & & 1 \\
\hline Portneuf R WS-1 & 34 & 6.2 & 81 & 62 & 280 & 64 & 38 & 1060 & 270 & 62 & 0.8 & PR & & 8 \\
\hline Portneuf R WS-2 & 41 & 6.3 & 85 & 60 & 275 & 48 & 47 & 1060 & 259 & 53 & 0.7 & & & 1 \\
\hline Corral Creek W-1 & 42 & 6.5 & 101 & 237 & 701 & 263 & 28 & 2845 & 898 & 41 & 2.3 & $\mathrm{CC}$ & & 6 \\
\hline Corral Creek W-12 & 41 & 6.8 & 97 & 242 & 620 & 246 & 30 & 2763 & 908 & 43 & 3.5 & & & 6 \\
\hline Corral Creek W-13 & 41 & 6.6 & 101 & 233 & 697 & 263 & 30 & 2723 & 896 & 40 & 2.4 & & & 6 \\
\hline Corral Creek W-14 & 36 & 6.6 & 99 & 233 & 649 & 253 & 30 & 2803 & 884 & 40 & 2.5 & & & 6 \\
\hline Dyer W & 21 & 7.7 & 50 & 3 & 50 & 13 & 68 & 188 & 1 & 61 & & $D \& A$ & & 1 \\
\hline Anderson W & 20 & 7.7 & 45 & 7 & 50 & 10 & 111 & 199 & 0 & 45 & & & & 1 \\
\hline Rockland W-1 & 20 & 7.6 & 27 & 13 & 37 & 8 & 160 & 180 & 15 & 28 & 0.6 & RL1 & & 5 \\
\hline
\end{tabular}

${ }^{a}$ Well/spring types - W: well, HS: hot spring, WS: warm spring, S: spring, G: geyser; ${ }^{b}$ these map codes are used to define the springs/wells in Fig. 2 , ${ }^{\mathrm{c}}$ water types are - I: Na-Cl (12 samples), II: $\mathrm{Na}_{-} \mathrm{HCO}_{3}-\mathrm{Cl}+\mathrm{Ca}-\mathrm{SO}_{4}$ (13 samples), III: Na-HCO $-\mathrm{Cl}$ (3 samples), IV: Ca-Cl (1 sample), V: Ca-SO 4 (4 samples), and VI: Ca-HCO 3 (17 samples); ${ }^{\mathrm{d}}$ data sources 1: Ralston et al. (1981), 2: Mitchell (1976a), 3: Young and Mitchell (1973), 4: Dion (1969), 5: Parliman and Young (1992), 6: Mitchell (1976b), 7: Souder (1985), 8: Mitchell et al. (1980). 
be found elsewhere (e.g., Palmer et al., 2014; Neupane et al., 2014; Mattson et al., 2015).

\subsection{Missing components}

The MEG approach requires that measured water composition include all components present in the reservoir mineral assemblage (RMA). For aluminosilicate minerals, this requires measured values of $\mathrm{Al}$ that are often not available in historical composition database. For water compositions without measured $\mathrm{Al}$, an Al-bearing mineral (e.g., $\mathrm{K}$ feldspar) was used as a proxy for Al during geochemical modeling as suggested by Pang and Reed (1998).

\subsection{Reservoir mineral assemblage}

Based on the geology of southeastern Idaho and literature assessment of secondary minerals generally associated with the dominant rock and water types, we assumed reservoir mineral assemblages (RMAs) consisting of idealized clays, zeolites, carbonates, feldspars, and silica polymorphs (chalcedony) to estimate equilibrium temperatures using RTEst. Recently, Mattson et al. (2015) reported that the RTEst results in similar temperature estimates for the same water compositions when applied with slightly different RMAs. Selection of one or two unrepresentative minerals in the RMAs produced larger uncertainties in estimated temperatures than the estimated temperatures themselves because of poor convergence (Mattson et al., 2015). Therefore, while selecting the RMAs for RTEst, it is recommended to consider local geology, water chemistry (e.g., $\mathrm{pH}$ ), and expected range of the reservoir temperatures. For more detailed information on selecting RMAs, see Palmer et al. (2014).

Using an appropriate RMA and measured water composition, RTEst estimates an equilibrium reservoir temperature (as well as a fugacity of $\mathrm{CO}_{2}$ and mixing with non-thermal water or boiling) by minimizing an objective function $(\Phi)$ that is the weighted sum of squares of the saturation indexes for the selected equilibrium minerals:

$\Phi=\sum\left(\mathrm{SI}_{i} w_{i}\right)^{2}$,

where $\mathrm{SI}_{i}=\log \left(Q_{i} / K_{i, T}\right)$ for the $i$ th equilibrium mineral ( $Q_{i}$ and $K_{i, T}$ are the ion activity product and temperaturedependent equilibrium constant, respectively for the $i$ th mineral) and $w_{i}$ is the weighting factor for the $i$ th mineral.

The weighting factors ensure that each mineral that contributes to the equilibrium state is considered equally and the results are not skewed by reaction stoichiometry or differences in analytical uncertainty. There are three options for weighting factors in RTEst: inverse of variance, normalization, or unit weights. They are discussed in more detail by Palmer et al. (2014). In this paper, we used a normalization method for weighting, which assumes that the analytical errors for all thermodynamic components expressed as basis species are equal and that the thermodynamic activity of

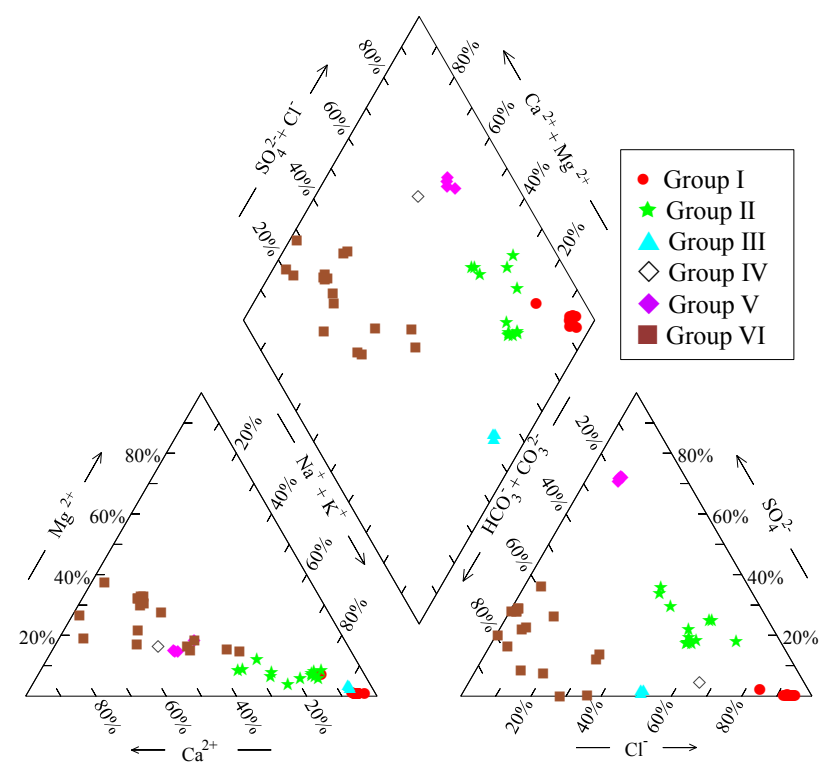

Figure 2. Reported chemistry of waters measured from several hot/warm springs and wells located in southeastern Idaho.

water is unity and is invariant. Examples of weighting factors (normalization factors) for several minerals are given in Palmer et al. (2014).

\section{Results and discussion}

\subsection{Southeastern Idaho spring/well waters}

Compositions of waters from hot/warm springs and wells in southeastern Idaho are presented in Table 2 . The $\mathrm{pH}$ values of southeastern Idaho thermal waters are circum-neutral, ranging from 6.2 to 8.1, with arithmetic mean, median, and standard deviation of $6.87,6.70$, and 0.51 , respectively; the field temperatures range between 20 and $84^{\circ} \mathrm{C}$. The aqueous chemistry of these thermal waters shows a large range in total dissolved solids (TDS) from about $250 \mathrm{mg} \mathrm{L}^{-1}$ (Downata Hot Spring) to more than $14000 \mathrm{mg} \mathrm{L}^{-1}$ (E. Bingham Well).

The dominant cations in the southeastern Idaho thermal waters are $\mathrm{Na}$ and $\mathrm{Ca}$ with minor amounts of $\mathrm{Mg}$ (Fig. 2). The thermal waters include samples dominated by $\mathrm{Cl}, \mathrm{HCO}_{3}$, or $\mathrm{SO}_{4}$ while others appear to be dominated by more than one anion. Hierarchical cluster analysis using Ward's (1963) method as implemented in SYSTAT 13 (SYSTAT Software, Inc.) was performed using the 6 Piper diagram (Fig. 2) end-members $\left(\mathrm{Ca}^{2+}, \mathrm{Mg}^{2+}, \mathrm{Na}^{+}+\mathrm{K}^{+}, \mathrm{Cl}^{-}, \mathrm{HCO}_{3}^{-}+\mathrm{CO}_{3}^{2-}\right.$, $\mathrm{SO}_{4}^{2-}$ ) for classifying water compositions. Six compositional groups were identified within the 50 thermal water samples - Group I: Na-Cl (12 samples), Group II: $\mathrm{Na}-\mathrm{HCO}_{3}-$ $\mathrm{Cl}+\mathrm{Ca}-\mathrm{SO}_{4}$ (13 samples), Group III: Na-HCO $-\mathrm{Cl}$ (3 samples), Group IV: $\mathrm{Ca}-\mathrm{Cl}$ (1 sample), Group V: $\mathrm{Ca}-\mathrm{SO}_{4}$ (4 samples), and Group VI: $\mathrm{Ca}-\mathrm{HCO}_{3}$ (17 samples) (Table 2). These groups likely reflect differences in sources of water, water- 
rock interactions, and structural control of the local geothermal systems.

The $\mathrm{Na}-\mathrm{Cl}$ and $\mathrm{Ca}-\mathrm{SO}_{4}$ (Group I and $\mathrm{V}$, respectively) type waters may have originated via the water-rock interactions involving pockets of evaporites in the area. Oriel and Platt (1980) have reported the presence of evaporites (e.g., halite, gypsum, and alum) in Middle Jurassic sequences (Preuss Redbeds) in southeastern Idaho. Recently, Welhan et al. (2014) indicated that the high-salinity waters in some deep wildcat petroleum wells may be related to either dissolution of salts from the Preuss evaporites or magmatic waters from a zone as deep as $12-14 \mathrm{~km}$ under the BVF in the foldthrust belt. However, all $\mathrm{Na}-\mathrm{Cl}$ (Group I) type waters considered in this study are from the surface expressions (hot/warm springs) or from shallow wells and may have originated via water-rock interactions involving evaporites. This type of water is also reported from the Raft River geothermal area (RRGA) located to the west of the present study area (Ayling and Moore, 2013). All Ca-SO 4 (Group V) type waters are from hot springs near Bear Lake, located near the IdahoWyoming-Utah border. Deep sourced water from a nearby deep wildcat petroleum well (N Eden Federal well with depth $>2500 \mathrm{~m}$ ) has a very high $\mathrm{SO}_{4}$ concentration; however, this water has low $\mathrm{Ca}$ concentration and high $\mathrm{Na}$ concentration (Souder, 1985). The Ca-SO 4 (Type V) type waters that the Bear Lake hot springs issue may have separate sources of $\mathrm{Ca}$ and $\mathrm{SO}_{4}$, or there may be cation exchange reactions involving $\mathrm{Ca}$ and $\mathrm{Na}$ along the flow path.

The $\mathrm{Ca}-\mathrm{HCO}_{3}$ (Group VI) type waters are scattered throughout the area. These waters typically exhibit low $\mathrm{Cl}$ concentrations (Table 2). With some exceptions (e.g., Black River warm spring, Corral Creek wells, Soda Geyser, Pescadero Warm Spring), these waters also have a low $\mathrm{SO}_{4}$ concentration. This type of water is generally regarded as a product of the interaction of groundwater with Ca-rich rocks at shallower depth. In the adjoining eastern Snake River Plain (ESRP), the $\mathrm{Ca}-\mathrm{HCO}_{3}$ (Group VI) type water represents the water in the active part of the ESRP aquifer whereas the deeper waters in ESRP area are $\mathrm{Na}-\mathrm{HCO}_{3}$ type (Mann, 1986; McLing et al., 2002).

Only one sample represents $\mathrm{Ca}-\mathrm{Cl}$ (Group IV) type water, the Rockland W-2 well located in the westernmost part of the study area (Fig. 1). Although this water has some similarity with the $\mathrm{Ca}-\mathrm{HCO}_{3}$ (Group VI) and $\mathrm{Ca}-\mathrm{SO}_{4}$ (Group V) types of water in terms of high $\mathrm{Ca}$ content compared to its $\mathrm{Na}$ and $\mathrm{K}$ concentrations, its high $\mathrm{Cl}$ and low $\mathrm{Na}$ concentrations make it difficult to assign it as a direct product of a particular type of water-rock interaction.

The remaining two types of waters are mixed waters $-\mathrm{Na}$ $\mathrm{HCO}_{3}-\mathrm{Cl}$ (Group III) and $\mathrm{Na}-\mathrm{HCO}_{3}-\mathrm{Cl}+\mathrm{Ca}-\mathrm{SO}_{4}$ (Group II). The cluster analysis did not identify a separate $\mathrm{Na}-\mathrm{HCO}_{3}$ type water, as it is a representative of deep waters in the adjoining ESRP. It is more likely that these waters are $\mathrm{Na}-\mathrm{Cl}$ type waters that have interacted with carbonate with or without gypsum/anhydride.

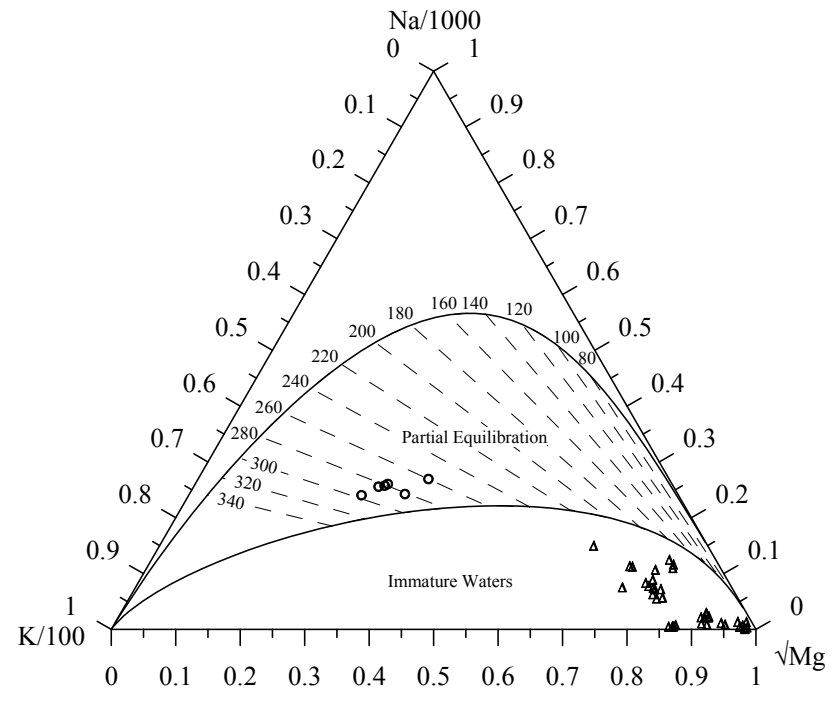

Figure 3. Southeastern Idaho waters from hot springs and wells plotted on Giggenbach diagram (Giggenbach, 1988). All partially equilibrated waters are of $\mathrm{Na}-\mathrm{Cl}$ (Group I) type waters.

\subsection{Southeastern Idaho geothermal reservoir temperatures}

\subsubsection{Giggenbach diagram}

When plotted on a Giggenbach diagram (Giggenbach, 1988), the majority of the southeastern Idaho waters in this study are in the immature zone with some waters in the zone of partial equilibration (Fig. 3). The partially equilibrated waters in Fig. 3 are from hot springs and wells near Preston, Idaho (Battle Creek and Squaw hot springs), and distribution of these waters on Giggenbach diagram indicates that these waters could have interacted with rock at a temperature range of $260-300{ }^{\circ} \mathrm{C}$. The immaturity reflects their low $\mathrm{Na}$ content as well as their higher $\mathrm{Mg}$ content (Giggenbach, 1988). Waters with high $\mathrm{Mg}$ are deemed to be unsuitable for some traditional solute geothermometry, although there have been efforts to develop a Mg correction (e.g., Fournier and Potter, 1979).

\subsubsection{Temperature estimated by multicomponent equilibrium geothermometry}

Estimates of reservoir temperatures for southeastern Idaho thermal waters shown in Table 2 were made using RTEst and several conventional geothermometers (Table 3). The RMAs that were used in RTEst consisted of representative minerals (Mg-bearing minerals - clinochlore, illite, saponite, disordered dolomite; Na-bearing minerals - paragonite, saponite; $\mathrm{K}$-bearing minerals $-\mathrm{K}$ feldspar, mordenite $\mathrm{K}$, illite; Cabearing minerals - calcite, disordered dolomite; and chalcedony). For thermal waters that do not have measured $\mathrm{Al}$ 
Table 3. Temperature $\left({ }^{\circ} \mathrm{C}\right)$ estimates for southeastern Idaho thermal waters RTEst and other geothermometers.

\begin{tabular}{|c|c|c|c|c|c|c|}
\hline Springs/wells ${ }^{\mathrm{a}}$ & $\mathrm{T}^{\mathrm{b}} \pm \sigma^{\mathrm{c}}$ & Quartz $^{\mathrm{d}}$ & Chalcedony ${ }^{\mathrm{e}}$ & Silica $^{\mathrm{f}}$ & $\mathrm{Na}-\mathrm{K}-\mathrm{Ca}^{\mathrm{g}}$ & Types $^{h}$ \\
\hline Woodruff HS & $97 \pm 3$ & 78 & 47 & 49 & 56 & I \\
\hline E. Bingham W & $161 \pm 4$ & 117 & 88 & 88 & 193 & \\
\hline Squaw HS-1 & $179 \pm 9$ & 151 & 125 & 123 & 204 & \\
\hline Squaw HS-2 & $157 \pm 6$ & 151 & 125 & 123 & 183 & \\
\hline Squaw HS W-1 & $175 \pm 5$ & 152 & 127 & 125 & 229 & \\
\hline Squaw HS W-2 & $174 \pm 6$ & 150 & 124 & 122 & 217 & \\
\hline Squaw HS W-3 & $171 \pm 7$ & 156 & 132 & 129 & 216 & \\
\hline Battle Creek HS-1 & $169 \pm 5$ & 142 & 116 & 114 & 205 & \\
\hline Battle Creek HS-2 & $175 \pm 6$ & 141 & 115 & 113 & 215 & \\
\hline Battle Creek HS-3 & $170 \pm 5$ & 142 & 116 & 114 & 202 & \\
\hline Battle Creek HS-4 & $171 \pm 4$ & 136 & 109 & 107 & 204 & \\
\hline Wayland HS-1 & $175 \pm 5$ & 125 & 97 & 97 & 230 & \\
\hline Alpine WS & $98 \pm 9$ & 92 & 61 & 63 & 92 & II \\
\hline Wayland HS-2 & $144 \pm 7$ & 114 & 85 & 85 & 84 & \\
\hline Treasurton WS-1 & $111 \pm 3$ & 105 & 76 & 77 & 78 & \\
\hline Treasurton WS-2 & $111 \pm 9$ & 105 & 76 & 77 & 113 & \\
\hline Cleavland WS & $119 \pm 7$ & 112 & 83 & 84 & 106 & \\
\hline Maple Grove HS-1 & $126 \pm 4$ & 106 & 77 & 78 & 97 & \\
\hline Maple Grove HS-2 & $123 \pm 4$ & 128 & 101 & 100 & 73 & \\
\hline Maple Grove HS-3 & $124 \pm 3$ & 129 & 101 & 101 & 82 & \\
\hline Maple Grove HS-4 & $115 \pm 7$ & 104 & 74 & 75 & 54 & \\
\hline Maple Grove HS-5 & $126 \pm 6$ & 128 & 100 & 99 & 67 & \\
\hline Maple Grove HS-6 & $122 \pm 5$ & 115 & 86 & 87 & 97 & \\
\hline Auburn HS & $107 \pm 9$ & 117 & 88 & 88 & 104 & \\
\hline Johnson S & $116 \pm 13$ & 130 & 103 & 102 & 134 & \\
\hline Ben Meek W-1 & $106 \pm 7$ & 131 & 104 & 103 & 86 & III \\
\hline Ben Meek W-2 & $106 \pm 4$ & 125 & 97 & 97 & 72 & \\
\hline Ben Meek W-3 & $109 \pm 4$ & 131 & 103 & 102 & 73 & \\
\hline Rockland-W2 & $110 \pm 7$ & 118 & 90 & 90 & 93 & IV \\
\hline Bear Lake HS-1 & $113 \pm 7$ & 64 & 66 & 73 & & V \\
\hline Bear Lake HS-2 & $111 \pm 7$ & 98 & 68 & 69 & 94 & \\
\hline Bear Lake HS-3 & $107 \pm 8$ & 92 & 61 & 63 & 92 & \\
\hline Bear Lake HS-4 & $121 \pm 4$ & 86 & 55 & 57 & 90 & \\
\hline Downata HS & $97 \pm 3$ & 78 & 47 & 49 & 49 & VI \\
\hline Black River WS & $103 \pm 3$ & 83 & 52 & 55 & 85 & \\
\hline Pescadero WS & $68 \pm 8$ & 81 & 49 & 52 & 41 & \\
\hline Henry WS & $60 \pm 16$ & 92 & 61 & 63 & 89 & \\
\hline Steamboat HS & $96 \pm 11$ & 100 & 99 & 46 & & \\
\hline Soda Springs G & $59 \pm 15$ & 86 & 55 & 57 & 88 & \\
\hline Lava HS-1 & $94 \pm 6$ & 82 & 51 & 53 & 67 & \\
\hline Lava HS-2 & $94 \pm 5$ & 86 & 55 & 57 & 64 & \\
\hline Portneuf R WS-1 & $100 \pm 6$ & 89 & 59 & 61 & 92 & \\
\hline Portneuf R WS-2 & $101 \pm 9$ & 99 & 69 & 70 & 111 & \\
\hline Corral Creek W-1 & $98 \pm 3$ & 77 & 45 & 48 & 98 & \\
\hline Corral Creek W-2 & $100 \pm 4$ & 79 & 48 & 51 & 97 & \\
\hline Corral Creek W-3 & $98 \pm 3$ & 79 & 48 & 51 & 99 & \\
\hline Corral Creek W-4 & $98 \pm 3$ & 79 & 48 & 51 & 100 & \\
\hline Dyer W & $121 \pm 3$ & 117 & 88 & 88 & 57 & \\
\hline Anderson W & $144 \pm 4$ & 143 & 117 & 115 & 74 & \\
\hline Rockland-W1 & $31 \pm 4$ & 165 & 142 & 138 & 88 & \\
\hline
\end{tabular}

${ }^{a}$ HS: hot spring, WS: warm spring, W: well; ${ }^{b}$ RTEst-estimated temperature; ${ }^{c} \sigma$ is standard error in each RTEst optimized temperature; ${ }^{\mathrm{d}}$ quartz no steam loss, Fournier (1977); ${ }^{\mathrm{e}}$ Fournier (1977); ${ }^{\mathrm{f}}$ Arnórsson et al. (1983); ${ }^{\mathrm{g}}$ Fournier and Truesdell (1973), Mg correction applied according to Fournier and Potter II (1979); ${ }^{\mathrm{h}}$ water types are - I: Na-Cl (12 samples), II: $\mathrm{Na}-\mathrm{HCO}_{3} \mathrm{Cl}+\mathrm{Ca}-\mathrm{SO}_{4}$ (13 samples), III: $\mathrm{Na}-\mathrm{HCO}_{3}-\mathrm{Cl}$ (3 samples), IV: $\mathrm{Ca}-\mathrm{Cl}$ (1 sample), V: $\mathrm{Ca}-\mathrm{SO}_{4}$ (4 samples), and VI: $\mathrm{Ca}-\mathrm{HCO}_{3}$ (17 samples). 

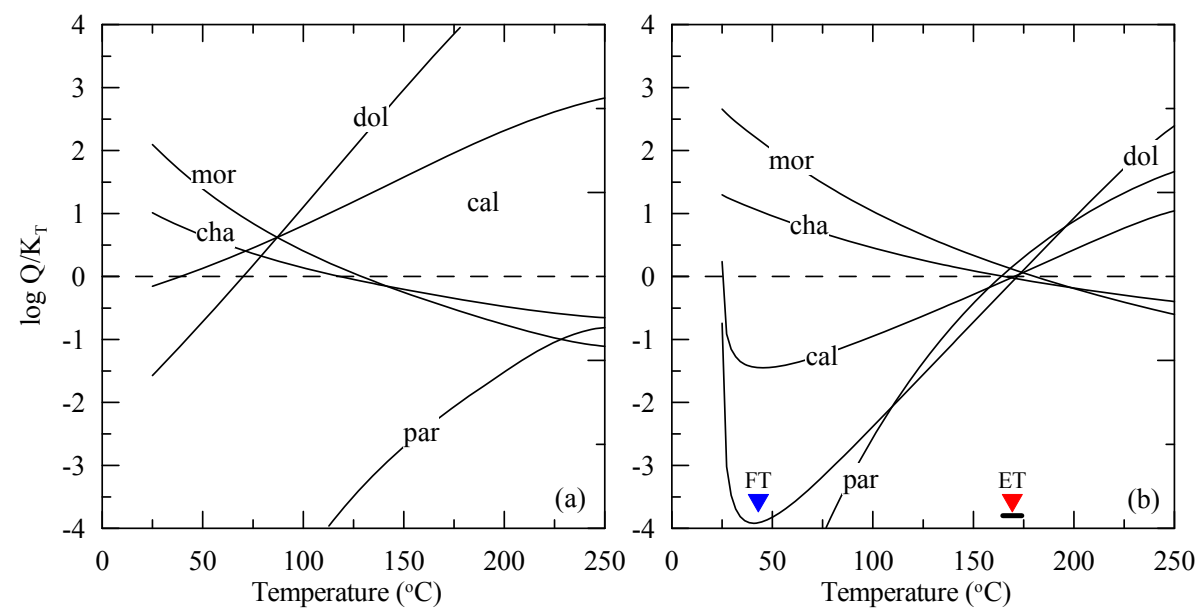

Figure 4. Temperature estimation for Battle Creek hot spring near Preston, Idaho. (a) The $\log Q / K_{T}$ curves for minerals calculated using original water chemistry with $\mathrm{K}$ feldspar used as a proxy for $\mathrm{Al}$, (b) optimized $\log Q / K_{T}$ curves (FT: field temperature (43 $\left.{ }^{\circ} \mathrm{C}\right)$; ET: estimated temperature $\left(169^{\circ} \mathrm{C}\right)$, the dark horizontal bar below ET represents the \pm standard error for the estimated temperature $\left( \pm 5^{\circ} \mathrm{C}\right)$; cal: calcite, cha: chalcedony, dol: disordered dolomite, mor: mordenite K, and par: paragonite).

concentration, a value determined from assumed equilibrium with $\mathrm{K}$ feldspar was used in the calculations.

In MEG, the reservoir temperature is estimated by assuming a representative RMA with which the fluid in the reservoir is believed to have equilibrated. Next, the activities of the chemical species in solution are determined and the saturation indices $\left[\mathrm{SI}=\log \left(Q / K_{T}\right)\right]$ calculated using the laboratory measured temperature of the sample. This calculation is repeated for a range of temperatures and the resulting SIs recalculated. The apparent reservoir temperature is the one at which all minerals in the RMA are in equilibrium with the reservoir fluid as indicated by near-zero $\log Q / K_{T}$ values on a $\log \left(Q / K_{T}\right)$ versus temperature plot $\left[\log \left(Q / K_{T}\right)\right.$ plot] (Reed and Spycher, 1984; Bethke, 2008). In other words, reservoir minerals in equilibrium with the fluid at depth should yield a common equilibrium temperature with a nearzero $\log \left(Q / K_{T}\right)$ value for each mineral at the same temperature; this common equilibrium temperature is assumed to be the reservoir temperature. If all the $\log \left(Q / K_{T}\right)$ curves do not show a common temperature convergence, then it suggests that there exists errors in analytical data, the selected mineral assemblage does not represent the actual mineral assemblage in the reservoir, or the sampled water must have been subjected to composition-altering physical and chemical processes during its ascent from the reservoir.

Figure 4 a shows typical $\log \left(Q / K_{T}\right)$ curves of the RMA (calcite, chalcedony, disordered dolomite, mordenite $\mathrm{K}$, and paragonite) used for the reported Battle Creek hot spring-1 water compositions. The $\log \left(Q / K_{T}\right)$ curves of these minerals intersect the $\log \left(Q / K_{T}\right)=0$ at a wide range of temperatures, ranging from $40^{\circ} \mathrm{C}$ (calcite) to over $250^{\circ} \mathrm{C}$ (paragonite), making the $\log \left(Q / K_{T}\right)$ curves derived from the reported water chemistry minimally useful for estimating tem- perature. The range of equilibration temperature for the assumed RMA is a reflection of physical and chemical processes that may have modified the Battle Creek hot spring-1 water composition during its ascent to the sampling point.

Three common composition-altering processes are degassing, mixing, and boiling. In particular, the loss of $\mathrm{CO}_{2}$ from geothermal water due to degassing has a direct effect on $\mathrm{pH}$, and it is often indicated by oversaturation of calcite (Palandri and Reed, 2001). Similarly, dilution of thermal water by cooler water or enrichment of solutes by boiling is indicated by lack of convergence of $\log \left(Q / K_{T}\right)$ curves over a small temperature range. In principle, these composition-altering processes can be taken into account by simply adding them into the measured water composition and looking for convergence of the saturation indices of the chosen mineral assemblage, but such a graphical approach becomes cumbersome even for two variables (e.g., temperature and $\mathrm{CO}_{2}$ ).

To account for possible composition-altering processes, RTEst was used to simultaneously estimate a reservoir temperature and optimize the amount of $\mathrm{H}_{2} \mathrm{O}$ (to account for mixing or boiling) and the fugacity of $\mathrm{CO}_{2}$ (to account for degassing) (Palmer et al., 2014). The optimized results for Battle Creek hot spring-1 are shown in Figure 4b. Compared to the $\log \left(Q / K_{T}\right)$ curves calculated using the reported water compositions (Fig. 4a), the optimized curves (Fig. 4b) converge to $\log \left(Q / K_{T}\right)=0$ within a narrow temperature range (i.e., $169 \pm 5^{\circ} \mathrm{C}$ ).

The optimized temperatures and composition parameters for the other southeastern Idaho waters reported in Table 2 were estimated using RTEst in the same manner. The estimated reservoir temperatures and associated standard errors are summarized in Table 3. 
Table 4. Mean and standard deviation ${ }^{\mathrm{a}}$ of estimated temperature for each group of water.

\begin{tabular}{|c|c|c|c|c|c|c|}
\hline Geothermometer & Group $1^{\mathrm{b}}$ & Group $2^{\mathrm{c}}$ & Group $3^{\mathrm{d}}$ & Group $4^{\mathrm{e}}$ & Group $5^{f}$ & Group $6^{\mathrm{g}}$ \\
\hline RTEst & $165 \pm 22$ & $119 \pm 11$ & $107 \pm 1$ & 110 & $113 \pm 6$ & $98 \pm 22$ \\
\hline Chalcedony ${ }^{\mathrm{h}}$ & $110 \pm 24$ & $85 \pm 13$ & $102 \pm 4$ & 90 & $62 \pm 5$ & $67 \pm 28$ \\
\hline $\mathrm{Na}-\mathrm{K}-\mathrm{Ca}^{\mathrm{i}}$ & $196 \pm 46$ & $91 \pm 21$ & $77 \pm 8$ & 93 & $87 \pm 10$ & $79 \pm 21$ \\
\hline
\end{tabular}

\subsubsection{Temperature estimates with traditional geothermometers}

In addition to RTEst, other traditional geothermometers were also compared (Table 3, Fig. 5). Because most of the waters from thermal springs and wells in southeastern Idaho are geochemically immature (Fig. 3), the use of traditional geothermometers to estimate their temperatures is unreliable. Temperatures obtained with silica polymorphs and Na-K$\mathrm{Ca}$ geothermometers can be quite variable, compared with the RTEst temperatures. As shown in Table 4, group-wise mean chalcedony-based reservoir temperatures are consistently cooler than the mean RTEst-calculated reservoir temperature.

Chalcedony-based reservoir temperatures were calculated using the observed silica concentrations. On the other hand, RTEst reservoir temperatures were calculated with reconstructed solute concentrations (i.e., optimized for water gain/loss). For the majority of samples, the chalcedony-based temperatures are lower than the RTEst-estimated temperatures (Fig. 5a). In general, wherever RTEst indicates that the sample contains an appreciable fraction of additional water, the RTEst temperature is higher than the chalcedony-based temperature for that sample.

$\mathrm{Mg}$-corrected $\mathrm{Na}-\mathrm{K}-\mathrm{Ca}$ temperatures are relatively similar to the RTEst temperatures; however, the trend between mean RTEst and $\mathrm{Na}-\mathrm{K}-\mathrm{Ca}$ temperature varies with groups. In general, Na-K-Ca geothermometry predicts in cooler temperatures in the lower temperature range and hotter temperatures in the upper temperature range compared to the RTEst temperatures (Fig. 5b). The main weakness of Na-K$\mathrm{Ca}$ geothermometer is poor reliability in waters with a significant amount of Mg. Even the Mg-corrected Na-K-Ca temperature estimates have poor reliability if the $\mathrm{Mg}$ concentration in thermal waters is high and is controlled by nonchlorite minerals. In southeastern Idaho, the Mg concentration in thermal waters is likely to be controlled by carbonate minerals (limestone/dolomite) as these waters may have interacting with carbonate sequences in the reservoir or along the flow path. Compared to the RTEst temperatures, Na-K$\mathrm{Ca}$ temperatures are lower for all but Group 1 waters. The overprediction of temperature for Group 1 waters is likely
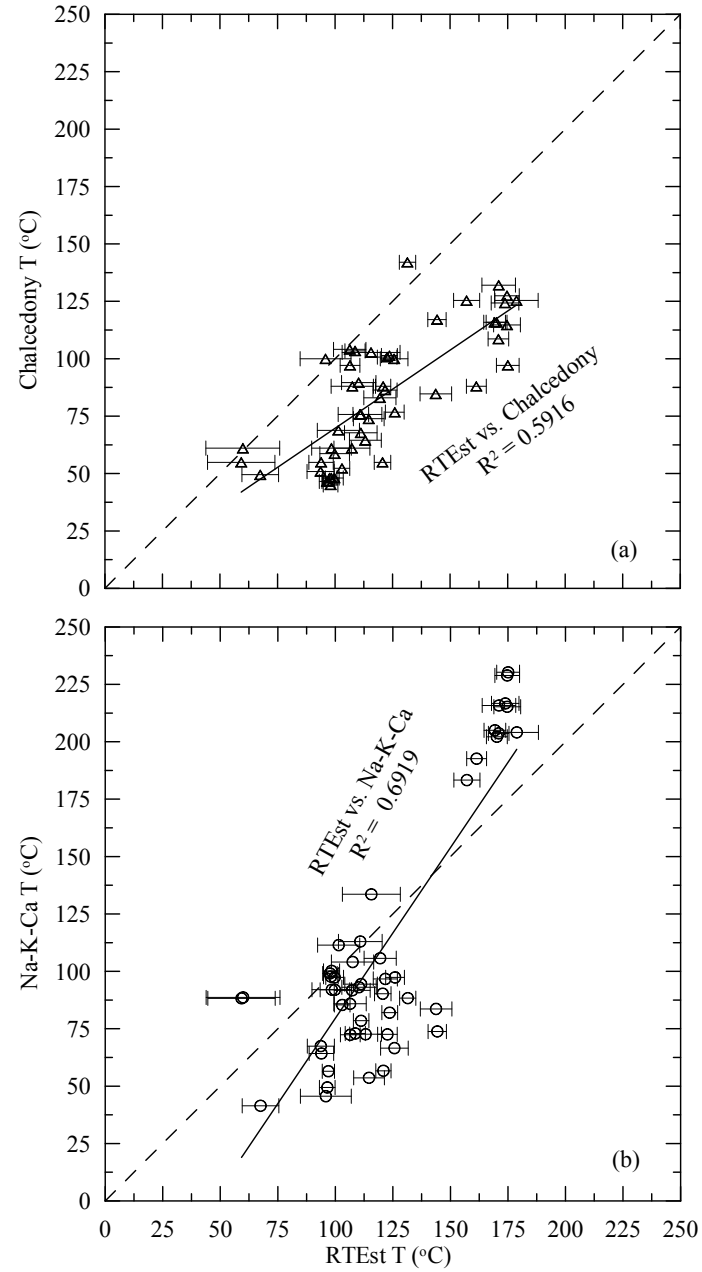

Figure 5. RTEst temperatures versus chalcedony (a) and Na-K$\mathrm{Ca}(\mathbf{b})$ temperatures for the southeastern Idaho thermal waters. Each horizontal bar represents 1 standard error on each side in RTEst temperature estimate.

caused by the disproportionate (relative to $\mathrm{Na}$ and $\mathrm{K}$ ) loss of $\mathrm{Ca}$ to calcite precipitation as suggested by Young and Lewis (1981). 


\subsubsection{Estimated temperature versus bottom-hole temperature of wildcat petroleum wells}

As reported in Table 1, some of the wildcat petroleum wells in the fold-thrust belt in southeastern Idaho have measured BHTs. In general, RTEst-calculated reservoir temperatures appear positively correlated with nearby BHTs, supporting the argument that MEG can be used to predict deep geothermal reservoir temperatures. The North Eden Federal 21-11 well $(2618 \mathrm{~m})$ is located east of the Bear Lake, near the border of Idaho, Utah, and Wyoming. This well has slightly lower BHT $\left(84^{\circ} \mathrm{C}\right)$ than the RTEst temperature estimates (107-121 with standard error \pm 4 to \pm 8 ) for nearby Bear Lake hot springs (represented by letter code BL in Fig. 1). Similarly, the RTEst temperature estimate for Alpine Spring (letter code AL in Fig. 1) $\left(98 \pm 9^{\circ} \mathrm{C}\right)$ is similar to the BHT of the nearest deep well, Black Mountain-1 $\left(4158 \mathrm{~m}, 120^{\circ} \mathrm{C}\right)$. However, there are some thermal features that have different RTEst-calculated reservoir temperatures than the BHTs of some nearby wells. For example, the BHTs measured for Federal $1-8\left(167^{\circ} \mathrm{C}\right)$ and Federal $1-13\left(172^{\circ} \mathrm{C}\right)$ are significantly higher than the estimated temperature $\left(68 \pm 8^{\circ} \mathrm{C}\right)$ for the closest spring (Pescadero Warm Spring with PD letter code in Fig. 1). In this case, it is important to note that BHTs of some nearby wells also varied slightly. For example, Bald Mountain-2 $(3830 \mathrm{~m})$ has a BHT of $140^{\circ} \mathrm{C}$ whereas the nearby Black Mountain-1 well $(4158 \mathrm{~m})$ has a BHT of $120^{\circ} \mathrm{C}$. Such variation in temperature at depth in nearby wells may suggest that some deep temperatures measured in wells are not equilibrated (i.e., disturbed by drilling) or could reflect variable proximity to the thermal water flow paths along fault or other heterogeneities.

The highest BHT was recorded for the King 2-1 well $\left(3927 \mathrm{~m}, 202^{\circ} \mathrm{C}\right)$, but there are no RTEst temperature estimates in the vicinity of this well. Similarly, there is no deep measured temperature in the vicinity of Battle Creek and Squaw hot springs near Preston. However, these hot springs discharge hot waters (up to $84^{\circ} \mathrm{C}$ ), and some of the recent shallow wells in the area are reportedly producing water with a temperature over $100^{\circ} \mathrm{C}$. New initiatives (e.g., Wood et al., 2015) would help further assess the geothermal potential of the Preston area system.

\section{Conclusions}

The geological setting coupled with the direct evidence of thermal expressions such as hot/warm springs in the area suggests that southeastern Idaho has good potential for geothermal resources. Our temperature estimates using RTEst with water compositions from southeastern Idaho thermal springs and wells indicate the presence of geothermal reservoirs at depth. Specifically, thermal waters of the Battle Creek hot springs and the Squaw Hot Springs suggest a promising geothermal prospect near Preston, Idaho. The US Department of Energy-sponsored new initiative in the Preston area with geological, geochemical, and geophysical approaches is expected to further assess the geothermal potential. In several other areas, oil and gas wildcat wells indicate presence of high temperature at depth; however, the moderate RTEst temperature estimates from nearby thermal springs and shallow wells might reflect mixing of local groundwater with deep thermal water and/or re-equilibration of high temperature thermal waters in a shallow low temperature zone.

Acknowledgements. Funding for this research was provided by the US Department of Energy, Office of Energy Efficiency \& Renewable Energy, Geothermal Technologies Program. We appreciate the help from Will Smith and Cody Cannon for this study. Reviews by John Welhan and an anonymous reviewer greatly improved the quality of this paper.

Edited by: H. Rüter

Reviewed by: J. Welhan and one anonymous referee

\section{References}

Armstrong, F. C. and Oriel, S. S.: Tectonic development of IdahoWyoming thrust bel, B. Am. Ass. Petrol. Geol, 49, 1847-1866, 1965.

Arnórsson, S., Gunnlaugsson, E., and Svavarsson, H.: The chemistry of geothermal waters in Iceland - III Chemical geothermometry in geothermal investigations, Geochimica et Cosmochimica Acta, 47, 567-577, 1983.

Avery, C.: Chemistry of thermal water and estimated reservoir temperatures in southeastern Idaho, north-central Utah, and southwestern Wyoming, 38th Field Conference, Wyoming Geological Association Guidebook, 347-353, 1987.

Ayling, B. and Moore, J.: Fluid geochemistry at the Raft River geothermal field, Idaho, USA: New data and hydrogeological implications, Geothermics, 47, 116-126, 2013.

Bethke, C. M.: Geochemical and Biogeochemical Reaction Modeling, Cambridge University Press, Cambridge, UK, 564 pp., 2008.

Blackwell, D. D., Kelley, S., and Steele, J. L.: Heat flow modeling of the Snake River Plain, Idaho, US Department of Energy Report for contract DE-AC07-761DO1570, 1992.

Cooper, D. C., Palmer, C. D., Smith, R. W., and McLing, T. L.: Multicomponent equilibrium models for testing geothermometry approaches, Proceedings of the 38th Workshop on Geothermal Reservoir Engineering Stanford University, Stanford, California, 11-13 February, 2013, SGP-TR-198, 10 pp., 2013.

D'Amore, F., Fancelli, R., and Caboi, R.: Observations on the application of chemical geothermometers to some hydrothermal systems in Sardinia, Geothermics, 16, 271-282, 1987.

Dansart, W. J., Kauffman, J. D., and Mink, L. L.: Overview of Geothermal Investigations in Idaho, 1980-1993, Idaho Water Resources Research Institute, University of Idaho, Moscow, Idaho, 1994.

Dion, N. P.: Hydrologic reconnaissance of the Bear River Basin in southeastern Idaho: Idaho Dept. of Water Resources, Water Inf. Bull. 13, 1969.

Dixon, J. S.: Regional structural synthesis, Wyoming salient of western overthrust belt, AAPG Bulletin, 66, 1560-1580, 1982. 
Fournier, R. O.: Chemical geothermometers and mixing models for geothermal systems, Geothermics, 5, 41-50, 1977.

Fournier, R. O. and Truesdell, A. H.: An empirical Na-K-Ca geothermometer for natural waters, Geochimica et Cosmochimica Acta, 37, 1255-1275, 1973.

Fournier, R. O. and Potter II, R. W.: Magnesium correction to the Na-K-Ca chemical geothermometer, Geochimica et Cosmochimica Acta, 43, 1543-1550, 1979.

Fournier, R. O., White, D. E., and Truesdell, A. H.: Geochemical indicators of subsurface temperature - 1: Basic assumptions, US Geol. Surv. J. Res. 2, 259-262, 1974.

Giggenbach, W. F.: Geothermal solute equilibria. Derivation of NaK-Mg-Ca geoindicators, Geochimica et Cosmochimica Acta, 52, 2749-2765, 1988.

Hull, C. D., Reed, M. H., and Fisher, K.: Chemical geothermometry and numerical unmixing of the diluted geothermal waters of the San Bernardino Valley Region of Southern California, GRC Transactions, 11, 165-184, 1987.

Mabey, D. R. and Oriel, S. S.: Gravity and magnetic anomalies in the Soda Springs region southeastern Idaho, US Geological Survey, Washington, DC, Geological Survey Professional Paper 646-E, 1970.

Mann, L. J.: Hydraulic properties of rock units and chemical quality of water for INEL-1: A 10,365-foot-deep test hole drilled at the Idaho National Engineering Laboratory, Idaho, US Geological Survey, Idaho Falls, Idaho, Geological Survey Water Resources Investigations Report 86-4020, p. 23, 1986.

Mattson, E. D., Smith, R. W., Neupane, G., Palmer, C. D., Fujita, Y., McLing, T. L., Reed, D. W., Cooper, D. C., and Thompson, V. S.: Improved Geothermometry Through Multivariate Reaction-path Modeling and Evaluation of Geomicrobiological Influences on Geochemical Temperature Indicators: Final Report No. INL/EXT-14-33959, Idaho National Laboratory (INL), Idaho Falls, Idaho, 2015.

McCurry, M., Hayden, K. P., Morse, L. H., and Mertzman, S.: Genesis of post-hotspot, A-type rhyolite of the Eastern Snake River Plain volcanic field by extreme fractional crystallization of olivine tholeiite, Bull. Volcanol. 70, 361-383, 2008.

McCurry, M., Welhan, J., Polun, S., Autenrieth, K., and Rodgers, D. W.: Geothermal potential of the Blackfoot Reservoir-Soda Springs Volcanic Field: A hidden geothermal resource and natural laboratory in SE Idaho, GRC Transactions, 35, 917-924, 2011.

McLing, T. L., Smith, R. W., and Johnson, T. M.: Chemical characteristics of thermal water beneath the eastern Snake River Plain, GSA Special Paper 353, 205-211, 2002.

Michard, G. and Roekens, E.: Modelling of the chemical components of alkaline hot waters, Geothermics, 12, 161-169, 1983.

Mitchell, J. C.: Geothermal Investigations in Idaho - Part 5, Geochemistry and geologic setting of the thermal waters of the northern Cache valley area, Franklin County, Idaho, Idaho Dep. Water Resources, Water Inf. Bull., No. 30, 1976a.

Mitchell, J. C.: Geothermal Investigations in Idaho - Part 6, Geochemistry and geologic setting of the thermal and mineral waters of the Blackfoot reservoir area, Caribou County, Idaho, Idaho Dep. Water Resources, Water Inf. Bull., No. 30, 1976 b.

Mitchell, J. C., Johnson, L. L, and Anderson, J. E.: Geothermal Investigations in Idaho - Part: 9, Potential for direct heat applica- tion of geothermal resources, Idaho Dep. Water Resources, Water Inf. Bull., No. 30, 1980.

Neupane, G., Smith, R. W., Palmer, C. D., and McLing, T. L.: Multicomponent equilibrium geothermometry applied to the Raft River geothermal area, Idaho: preliminary results, Geological Society of America, 45, p. 859, 2013.

Neupane, G., Mattson, E. D., McLing, T. L., Palmer, C. D., Smith, R. W., and Wood, T. R.: Deep geothermal reservoir temperatures in the Eastern Snake River Plain, Idaho using multicomponent geothermometry, Proceedings of the 39th Workshop on Geothermal Reservoir Engineering Stanford University, Stanford, California, 24-26 February 2014, SGP-TR-202, 12 pp., 2014.

Neupane G., Baum, J. S., Mattson, E. D., Mines, G. L., Palmer, C. D., and Smith, R. W.: Validation of multicomponent equilibrium geothermometry at four geothermal power plants, Proceedings of the 40th Workshop on Geothermal Reservoir Engineering Stanford University, Stanford, California, 26-28 January 2015, SGP-TR-204, 17 pp., 2015 a.

Neupane G., Mattson, E. D., McLing, T. L., Dobson, P. F., Conrad, M. E., Wood, T. R., Cannon, C., and Worthing, W.: Geothermometric temperature comparison of hot springs and wells in southern Idaho, GRC Transactions, 39, 495-502, 2015b.

Oriel, S. S. and Platt, L. B.: Geologic map of the Preston $1^{\circ} \times 2^{\circ}$ quadrangle, southeastern Idaho and western Wyoming, Miscellaneous Investigation Series, United States Geological Survey, Washington, DC, Department of Interior, Map I-1127, 1980.

Palandri, J. L. and Reed, M. H.: Reconstruction of in situ composition of sedimentary formation waters, Geochimica et Cosmochimica Acta, 65, 1741-1767, 2001.

Palmer, C. D., Ohly, S. R., Smith, R. W., Neupane, G., McLing, T., and Mattson, E.: Mineral selection for multicomponent equilibrium geothermometry, GRC Transactions, 38, 453-459, 2014.

Pang, Z. H. and Reed, M.: Theoretical chemical thermometry on geothermal waters: Problems and methods, Geochimica et Cosmochimica Acta, 62, 1083-1091, 1998.

Parliman, D. J. and Young, H. W.: Compilation of selected data for thermal-water wells and springs, 1921 through 1991, US Geological Survey, Boise, Idaho, Open-File Report 92-175, 1992.

Peiffer, L., Wanner, C., Spycher, N., Sonnenthal, E., Kennedy, B. M., and Iovenitti, J.: Optimized multicomponent vs. classical geothermometry: insights from mod-eling studies at the Dixie Valley geothermal area, Geothermics, 51, 154-169, 2014.

Pickett, K. E.: Physical volcanology, petrography, and geochemistry of basalts in the bimodal Blackfoot volcanic field, southeastern Idaho, MS Thesis, Idaho State University, Pocatello, Idaho, 2004.

Ralston, D. R., Arrigo, J. L., Baglio, J. V. Jr., Coleman, L. M., Souder, K., and Mayo, A. L.: Geothermal evaluation of the thrust area zone in southeastern Idaho, Idaho Water and Energy Research Institute, University of Idaho, 1981.

Reed, M. and Spycher, N.: Calculation of $\mathrm{pH}$ and mineral equilibria in hydrothermal waters with application to geothermometry and studies of boiling and dilution, Geochimica et Cosmochimica Acta, 48, 1479-1492, 1984.

Smith, R. W., Palmer, C. D., and Cooper, D.: Approaches for multicomponent equilibrium geothermometry as a tool for geothermal resource exploration, AGU Fall Meeting, San Francisco, 3-7 December, 2012. 
Souder, K. C.: The hydrochemistry of thermal waters of southeastern Idaho, western Wyoming, and northeastern Utah, MS Thesis, University of Idaho, Moscow, Idaho, 1985.

Spycher, N. F., Sonnenthal, E., and Kennedy, B. M.: Integrating multicomponent chemical geothermometry with parameter estimation computations for geothermal exploration, GRC Transactions, 35, 663-666, 2011.

Spycher, N., Peiffer, L., Sonnenthal, E. L., Saldi, G., Reed, M. H., and Kennedy, B. M.: Integrated multicomponent solute geothermometry, Geothermics, 51, 113-123, 2014.

Tester, J. W., Anderson, B. J., Batchelor, A. S., Blackwell, D. D., DiPippo, R., Drake, E. M., Garnish, J., Livesay, B., Moore, M. C., Nichols, K., Petty, S., Toksöz, M. N., and Veatch, R. W.: The future of geothermal energy - impact of enhanced geothermal systems (EGS) on the United States in the 21st century, Massachusetts Institute of Technology, Cambridge, Massachusetts, 372 pp., 2006.

Tole, M. P., Ármannsson, H., Pang, Z. H., and Arnórsson, S.: Fluid/mineral equilibrium calculations for geothermal fluids and chemical geothermometry, Geothermics 22, 17-37, 1993.

Ward, J. H., Jr.: Hierarchical grouping to optimize an objective function, J. Am. Stat. Assoc., 58, 236-244, 1963.

Welhan, J. A. and Gwynn, M.: High heat flow in the Idaho thrust belt: A hot sedimentary geothermal prospect, GRC Transactions 38, 1055-1066, 2014.

Welhan, J. A., Gwyunn, M., Payne, S., McCurry, M., Plummer, M., and Wood, T.: The Blackfoot volcanic field, southeast Idaho: a hidden high-temperature geothermal resource in the Idaho thrust belt, Proceedings of the 39th Workshop on Geothermal Reservoir Engineering Stanford University, Stanford, California, 2426 February 2014, SGP-TR-202, 13 pp., 2014
Williams, C. F., Reed, M. J., Mariner, R. H., DeAngelo, J., and Galanis Jr., S. P.: Assessment of moderate- and high-temperature geothermal resources of the United States, US Department of the Interior, US Geological Survey, Menlo Park, California, Fact Sheet 2008-3082, 2 pp., 2008.

Wood, T. R., Worthing, W., Cannon, C., Palmer, C., Neupane, G., McLing, T. L., Mattson, E., Dobson, P. F., and Conrad, M.: The Preston Geothermal Resources; Renewed Interest in a Known Geothermal Resource Area, Proceedings of the 40th Workshop on Geothermal Reservoir Engineering Stanford University, Stanford, California, 26-28 January 2015, SGP-TR-204, 14 pp., 2015.

Young, H. W. and Lewis, R. E.: Application of a Magnesium Correction to the Sodium-Potassium-Calcium Geothermometer for Selected Thermal Waters in Southeastern Idaho, GRC Transactions, 5, 145-148, 1981.

Young, H. W. and Mitchell, J. C.: Geothermal investigations in Idaho - Part 1: Geochemistry and geologic setting of selected thermal waters (No. NP-22003/1), US Geological Survey and Idaho Dept. of Water Administration, Boise, Idaho, 43 pp., 1973. 